\title{
APLIKASI PEMERIKSAAN PERSYARATAN YUDISIUM PADA PROGRAM STUDI TEKNIK INFORMATIKA UNIVERSITAS KRISTEN PETRA
}

\author{
Leo Willyanto Santoso, ${ }^{1}$, ulia $^{2}$, dan Luwuk Melly Julita ${ }^{3}$ \\ ${ }^{1,2,3}$ Program Studi Teknik Informatika, Fakultas Teknologi Industri, Universitas Kristen Petra \\ Jl. Siwalankerto 121-131, Surabaya 60236, Indonesia \\ E-mail: leow@petra.ac.id, yulia@petra.ac.id
}

\begin{abstract}
ABSTRAK: Program Studi (Prodi) Teknik Informatika Universitas Kristen Petra (UK Petra) melakukan proses pemeriksaan persyaratan kelulusan yudisium secara manual. Proses manual ini menghabiskan waktu yang cukup banyak serta kesulitan dalam menyesuaikan dengan kurikulum yang berlaku. Berdasarkan masalah yang dihadapi oleh Prodi Teknik Informatika, maka dilakukan pembuatan sebuah aplikasi untuk membantu mempercepat dan mempermudah pemeriksaan persyaratan kelulusan yudisium. Aplikasi ini meliputi pengaturan kurikulum, pengaturan bidang studi, pemeriksaan syarat yudisium, penentuan bidang studi mahasiswa serta laporan kelulusan yudisium. Aplikasi ini dibuat dengan menggunakan bahasa pemrograman ASP.Net dan database $M Y S Q L$. Berdasarkan hasil pengujian sistem, aplikasi yang dibuat telah mampu memenuhi kebutuhan Prodi Teknik Informatika dalam pemeriksaan persyaratan kelulusan yudisium.
\end{abstract}

Kata kunci: Sistem informasi, yudisium, kurikulum

\begin{abstract}
Informatics Engineering Department Petra Christian University do inspection process for judicium manually. This manual process spends considerable time and difficulty in adjusting to the curriculum and regulations. Based on the problems faced by the Department of Informatics, the author develops an application to help speed up and simplify the judicium inspection. This application includes the setting of curriculum, setting fields of study, inspection requirements judicium, determining areas of study graduated students and graduation report. This application was created using ASP.Net programming language and MYSQL as a database. Based on the testing processes, this application has been able to meet the needs of Department of Informatics in the judicium inspection process.
\end{abstract}

Keywords: Information system, judicium, curriculum

\section{PENDAHULUAN}

Program Studi (Prodi) Teknik Informatika UK Petra melaksanakan rapat yudisium setiap akhir semester, dimana salah satu agendanya melakukan pemeriksaan mata kuliah beserta persyaratan kelulusan. Pemeriksaan tersebut dilakukan dengan memeriksa transkrip nilai mahasiswa yang diperoleh dari BAAk (Biro Administrasi Akademik).

Proses-proses yang dilakukan pada pemeriksaan persyaratan kelulusan yudisium adalah penghitungan jumlah SKS yang telah diselesaikan, pemeriksaan mata kuliah yang diselesaikan, pemeriksaan persyaratan khusus dari prodi (seperti nilai TOEFL (Test of English as a Foreign Language) dan kegiatankegiatan yang wajib diikuti), serta penentuan bidang peminatan yang diambil mahasiswa. Akan tetapi proses tersebut masih dilakukan secara manual sehingga dapat menimbulkan beberapa kesulitan dan membutuhkan waktu yang lama dalam pengerjaannya.
Beberapa masalah yang dihadapi pada pemeriksaan secara manual tersebut seperti, kesulitan saat mencocokan mata kuliah yang menjadi syarat kelulusan dengan mata kuliah yang diambil oleh mahasiswa. Sedangkan kesalahan pada penghitungan jumlah SKS dan adanya mata kuliah yang terlewat saat diperiksa, juga mungkin terjadi karenanya.

Pemeriksaan persyaratan yudisium mahasiswa tidak lepas dari kurikulum Prodi Teknik Informatika. Kurikulum prodi telah mengalami beberapa kali perubahan. Perubahan tersebut menyebabkan proses pemeriksaan menjadi lebih sulit, karena harus menyesuaikan dengan kurikulum yang berlaku pada mahasiswa tersebut.

Untuk mengatasi masalah tersebut, dibutuhkan sistem yang mampu mempercepat dan mempermudah pemeriksaan persyaratan kelulusan yudisium. Sistem ini juga diharapkan mampu menyesuaikan diri dengan perubahan kurikulum yang ada.

Tujuan dari penelitian ini merancang dan membuat aplikasi pemeriksaan persyaratan kelulusan 
yudisium pada Prodi Teknik Informatika Universitas Kristen Petra yang dapat membantu mempercepat, mempermudah proses pengerjaannya, dan dapat bersifat fleksibel terhadap perubahan kurikulum.

Perumusan masalah yang terdapat dalam penelitian ini yaitu:

1. Bagaimana merancang proses pemeriksaan persyaratan kelulusan dengan tepat.

2. Bagaimana membuat sistem yang dapat membantu proses pemeriksaan persyaratan kelulusan.

3. Bagaimana cara mengatasi perubahan kurikulum yang terjadi.

4. Bagaimana membuat sistem yang dapat bersifat fleksibel.

5. Bagaimana membuat program yang dapat mudah digunakan oleh user.

Ruang lingkup penelitian ini dibatasi pada:

○ Input:

- Data mahasiswa: berisi data mahasiswa.

- Data transkrip mahasiswa: berisi data mata kuliah dan nilai mahasiswa.

- Data mata kuliah: berisi data mata kuliah.

- Data jenis mata kuliah: berisi data jenis-jenis mata kuliah. Terdiri dari:

- Mata kuliah pengembangan kepribadian (MPK)

- Mata kuliah keilmuan dan keterampilan (MKK)

- Mata kuliah keahlian berkarya (MKB)

- Mata kuliah perilaku berkarya (MPB)

- Mata kuliah keahlian berkarya pilihan (MKBP)

- Mata kuliah berkehidupan bermasyarakat (MBB)

- Data kurikulum: berisi data kurikulum yang digunakan.

- Data bidang studi: berisi bidang peminatan yang ada.

- Data Umum: berisi persyaratan khusus yang terdapat di Prodi Teknik Informatika yang juga merupakan syarat penentuan kelulusan yudisium.

- Data Kelulusan: berisi data yang menyimpan hasil dari pemeriksaan persyaratan kelulusan yudisium.

- Output:

- Bidang peminatan yang diambil oleh mahasiswa.

- Hasil pemeriksaan syarat kelulusan yudisium.

- Aplikasi yang dapat customized kurikulum dan syarat kelulusan.

Contoh:

Syarat kelulusan Mata Kuliah Keilmuan dan Keterampilan (MKK) pada bidang studi Infor- matika berjumlah 35 SKS, sedangkan pada bidang studi Teknologi Informasi berjumlah 36 SKS.

- Aplikasi yang dapat menangani perubahan aturan perpindahan bidang studi.

- Aplikasi yang mudah digunakan (user friendly).

- Aplikasi dibuat dengan ASP.Net dan database yang digunakan adalah $M Y S Q L$.

\section{PROSES YUDISIUM TEKNIK INFORMATIKA}

Program Studi Teknik Informatika Universitas Kristen Petra secara resmi didirikan dengan status TERDAFTAR melalui Surat Keputusan No. 147/DIKTI/ KEPT/1998, tanggal 25 Mei 1998 dan telah terakreditasi dengan nilai A berdasar Surat Keputusan 018/BAN-PT/Ak-XII/S1/VII/2009 pada tanggal 10 Juli 2009 [1].

Visi Prodi Teknik Informatika Universitas Kristen Petra adalah menjadi prodi yang mempunyai reputasi internasional dalam pengajaran, penelitian, dan pengabdian masyarakat serta menghasilkan lulusan yang mampu mendayagunakan teknologi informasi untuk meningkatkan kualitas hidup (enhancing human life) berdasarkan iman Kristen dan mampu berperan dalam pasar global [1].

Misi Prodi Teknik Informatika Universitas Kristen Petra adalah melaksanakan proses pendidikan, pengajaran, penelitian dan pengabdian masyarakat yang berkualitas, yang berfokus pada minat mahasiswa dan permintaan pasar global serta diarahkan untuk menyiapkan tenaga profesional yang handal dan mampu mengakomodasi perkembangan teknologi informasi di masa yang akan datang [1].

Prodi Teknik Informatika Universitas Kristen Petra melakukan proses pemeriksaan persyaratan kelulusan yudisium dengan memeriksa transkrip nilai mahasiswa sesuai dengan persyaratan dari kurikulum yang berlaku pada mahasiswa tersebut secara manual.

Untuk mendapatkan transkrip nilai mahasiswa, prodi meminta data transkrip mahasiswa tersebut ke BAAk (Biro Administrasi Akademik). Kemudian BAAk akan mengirimkan data transkrip mahasiswa dalam bentuk hardcopy. Kemudian data transkrip mahasiswa tersebut diperiksa dan dicocokkan dengan kurikulum yang berlaku untuk menentukan apakah mahasiswa tersebut lulus syarat yudisium dari segi transkrip nilai. Proses pemeriksaan ini masih dilakukan secara manual.

Berdasarkan isi dari Buku Pedoman Prodi Teknik Informatika tahun 2009 dan 2010:

- Pemilihan bidang studi dilakukan sesuai dengan ketentuan prodi.

- Mahasiswa bebas memilih bidang studi yang diminati dengan berkonsultasi terlebih dahulu kepada dosen wali dan kepala bidang studi. 
- Mahasiswa wajib menyelesaikan mata kuliah wajib sesuai bidang studi.

- Mahasiswa wajib menyelesaikan mata kuliah pilihan sesuai bidang studinya dengan besar prosentase yang sesuai dengan kurikulum yang berlaku terhadap mahasiswa tersebut.

Berdasarkan isi Buku Pedoman Prodi Teknik Informatika tahun 2007: Perhitungan prosentase Mata Kuliah Berkarya Pilihan (MKBP) yang diambil dilakukan saat mahasiswa telah menyelesaikan studinya di Teknik Informatika.

Mahasiswa dinyatakan lulus sarjana lokal dalam sidang yudisium apabila telah memenuhi syarat:

- Menyelesaikan minimal 144 SKS dan lulus mata kuliah sesuai ketentuan.

Contoh: Komposisi mata kuliah untuk mahasiswa angkatan 2010 dapat dilihat pada Tabel 1, Tabel 2 dan Tabel 3.

- IPK minimum 2,00.

- Jumlah mata kuliah dengan nilai D maksimum 14 SKS.

- Mengikuti Camp Pembinaan Mahasiswa Baru.

Tabel 1. Komposisi mata kuliah bidang studi Informatika [1]

\begin{tabular}{ll}
\hline No & $\begin{array}{c}\text { Jumlah } \\
\text { SKS }\end{array}$ \\
\hline 1. Mata Kuliah Pengembangan Kepribadian & 10 \\
(MPK) & \\
2. Mata Kuliah Keilmuan dan Keterampilan & 35 \\
(MKK) & \\
3. Mata Kuliah Keahlian Berkarya (MKB) & 49 \\
4. Mata Kuliah Perilaku Berkarya (MPB) & 13 \\
5. Mata Kuliah Keahlian Berkarya Pilihan & 33 \\
$\begin{array}{l}\text { (MKBP) } \\
\text { Mata Kuliah Berkehidupan Bermasya- }\end{array}$ & 4 \\
\hline & \\
\hline Jukat (MBB) & 144 \\
\hline
\end{tabular}

Tabel 2. Komposisi Mata Kuliah Bidang Studi Teknologi Informasi [1]

\begin{tabular}{lc}
\hline No Jenis Mata Kuliah & $\begin{array}{c}\text { Jumlah } \\
\text { SKS }\end{array}$ \\
\hline 1. Mata Kuliah Pengembangan Kepribadian & 10 \\
(MPK) & \\
2. Mata Kuliah Keilmuan dan Keterampilan & 36 \\
(MKK) & 51 \\
3. Mata Kuliah Keahlian Berkarya (MKB) & 13 \\
4. Mata Kuliah Perilaku Berkarya (MPB) \\
5. Mata Kuliah Keahlian Berkarya Pilihan \\
$\begin{array}{l}\text { (MKBP) } \\
\text { 6. Mata Kuliah Berkehidupan Bermasyarakat } \\
\text { (MBB) }\end{array}$ \\
\hline \multicolumn{1}{c}{ Jumlah SKS } \\
\hline
\end{tabular}

Tabel 3. Komposisi Mata Kuliah Bidang Studi Sistem Informasi Bisnis [1]

\begin{tabular}{|c|c|}
\hline No Jenis Mata Kuliah & $\begin{array}{c}\text { Jumlah } \\
\text { SKS }\end{array}$ \\
\hline $\begin{array}{l}\text { 1. Mata Kuliah Pengembangan Kepribadian } \\
\text { (MPK) }\end{array}$ & 10 \\
\hline $\begin{array}{l}\text { 2. Mata Kuliah Keilmuan dan Keterampilan } \\
\text { (MKK) }\end{array}$ & 39 \\
\hline 3. Mata Kuliah Keahlian Berkarya (MKB) & 48 \\
\hline 4. Mata Kuliah Perilaku Berkarya (MPB) & 13 \\
\hline $\begin{array}{l}\text { 5. Mata Kuliah Keahlian Berkarya Pilihan } \\
\text { (MKBP) }\end{array}$ & 30 \\
\hline $\begin{array}{l}\text { 6. Mata Kuliah Berkehidupan Bermasyarakat } \\
\text { (MBB) }\end{array}$ & 4 \\
\hline Jumlah SKS & 144 \\
\hline
\end{tabular}

- Mengikuti Studi Ekskursi Nasional atau dapat digantikan dengan mengikuti Seminar Teknologi Informasi bertaraf Nasional sebanyak 3 kali.

- Mengikuti Seminar Calon Lulusan dan Acara Pelepasan Calon Wisudawan.

- Memiliki nilai TOEFL minimal 450.

Mahasiswa dapat pindah dari satu program ke program yang lain dengan catatan [1]:

- Semua mata kuliah yang telah diambil pada program lama, akan menjadi mata kuliah pilihan jika tidak terdaftar sebagai mata kuliah wajib di program baru.

- Jika mahasiswa mengambil mata kuliah yang terletak satu baris pada tabel daftar padanan mata kuliah antar program, hanya diakui sebagai satu mata kuliah.

- Khusus untuk mata kuliah Jarkom dan Komdat (6 SKS) dapat menggantikan mata kuliah KDJK, tetapi tidak sebaliknya.

- Khusus untuk mata kuliah KB (3 SKS) dapat menggantikan mata kuliah PKB (2 SKS) tetapi tidak sebaliknya.

\section{ANALISIS DAN DESAIN SISTEM}

\section{Analisis Sistem Lama}

Program Studi Teknik Informatika Universitas Kristen Petra melakukan proses pemeriksaan persyaratan kelulusan yudisium dengan memeriksa transkrip nilai mahasiswa sesuai dengan persyaratan dari kurikulum yang berlaku pada mahasiswa tersebut secara manual.

Untuk mendapatkan transkrip nilai mahasiswa, prodi meminta data transkrip mahasiswa tersebut ke Biro Administrasi Akademik (BAAk). Kemudian BAAk akan mengirimkan data transkrip mahasiswa dalam bentuk hardcopy. Kemudian data transkrip 
mahasiswa tersebut diperiksa dan dicocokan dengan kurikulum yang berlaku untuk menentukan apakah mahasiswa tersebut lulus syarat yudisium dari segi transkrip nilai. Pemeriksaan yang dilakukan untuk satu transkrip mahasiswa memerlukan waktu kurang lebih 2 menit. (pada Gambar 1).

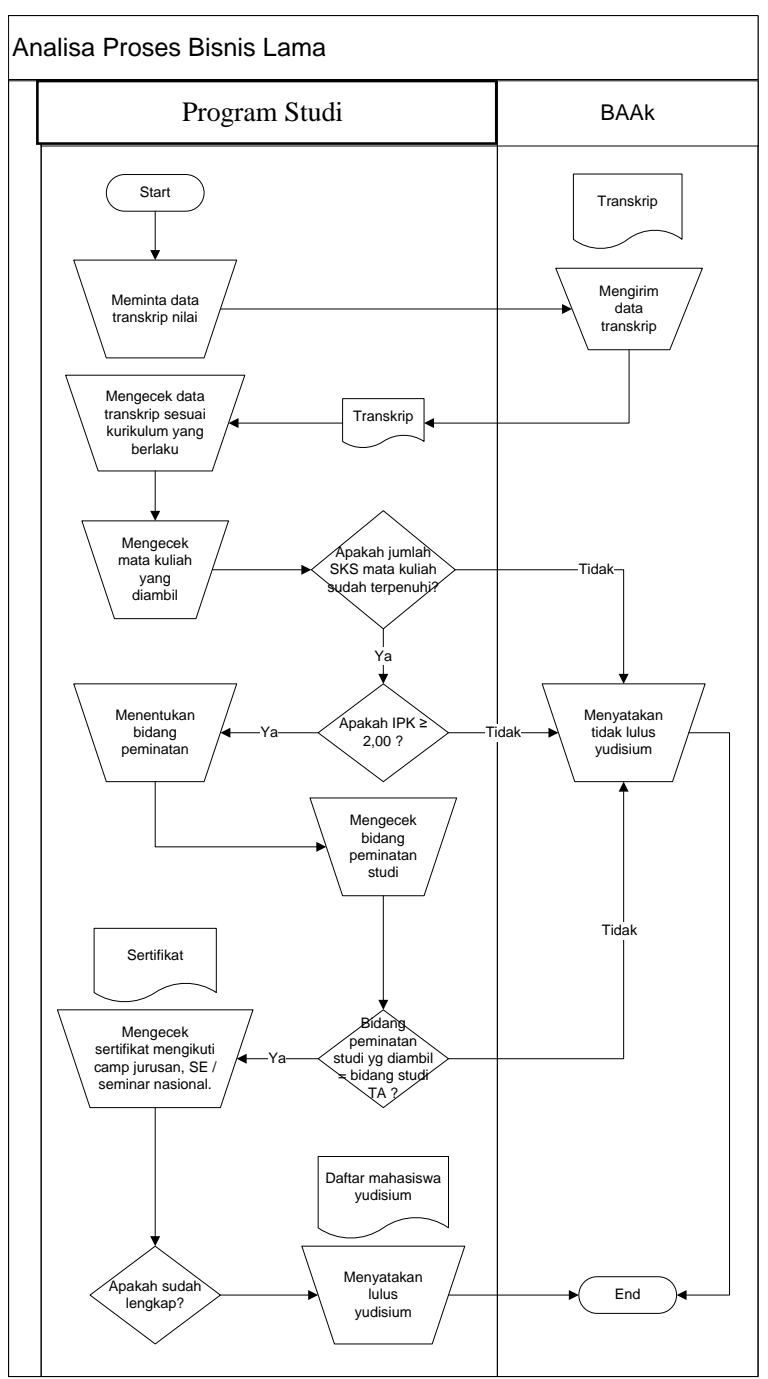

Gambar 1. Proses pemeriksaan syarat yudisium

\section{Analisa Permasalahan}

Proses-proses dalam pemeriksaan syarat-syarat yudisium masih dilakukan secara manual, karena itu terdapat beberapa masalah yang timbul. Pemeriksaan secara manual membutuhkan ketelitian dalam mengerjakannya dan waktu pengerjaan yang lama. Dalam prosesnya Prodi Teknik Informatika harus menghafal jenis-jenis mata kuliah yang ada kemudian memeriksa nilai mahasiswa dengan syarat nilai minimum yang terdapat pada masing-masing mata kuliah dan menghitung jumlah SKS yang telah lulus.

Adanya beberapa kurikulum yang digunakan, dengan syarat kelulusan yang berbeda-beda sehingga proses penentuan kelulusan harus disesuaikan terlebih dahulu. Kurikulum tersebut juga dapat berubah, sehingga mata kuliah wajib dan mata kuliah pilihan juga dapat berubah. Bidang studi yang ada pada setiap kurikulum memiliki mata kuliah wajib dan mata kuliah pilihan yang berbeda-beda. Didalam kurikulum juga terdapat perbedaan SKS pada mata kuliah dengan kode yang sama untuk bidang studi yang berbeda.

Pada perpindahan bidang studi oleh mahasiswa, ada mata kuliah yang diakui sebagai mata kuliah wajib jika sama, tapi bisa sebagai pilihan jika tidak ada di daftar mata kuliah pilihan dari bidang studi baru. Ada juga mata kuliah yang dapat menggantikan mata kuliah lain.

\section{Analisa Kebutuhan}

Berdasarkan analisa permasalahan, dibutuhkan aplikasi yang mampu membagi dan menghitung jumlah SKS sesuai dengan jenis mata kuliah dan bidang studi secara efektif dan efisien. Selain itu, desain database dari aplikasi harus dapat menyesuaikan dengan perubahaan kurikulum, pertambahan bidang studi, dan perpindahan bidang studi. Menggunakan aplikasi yang berbasis web yang diharapkan mampu mempermudah dalam pengambilan data transkrip dari BAAk. Program berbasis web yang akan digunakan adalah ASP.NET, sedangkan database yang digunakan adalah database MYSQL [2, 3]. Platform ini sesuai dengan aplikasi lain yang saling berintegrasi pada Prodi Teknik Informatika.

\section{Desain Sistem}

Berdasarkan dari analisa kebutuhan yang ada, maka dibuatlah aliran data yang digunakan sebagai rancangan dari sistem yang dibuat $[4,5]$. Context diagram sistem yang dibangun, dapat dilihat pada Gambar 2.

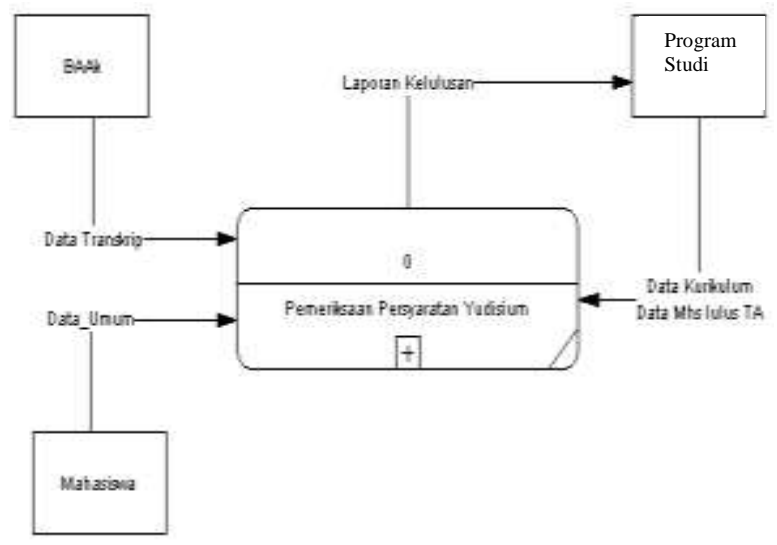

Gambar 2. Context Diagram 
Berdasarkan Gambar 2, Terdapat tiga entitas luar (terminator) yang berpengaruh pada sistem dalam proses yaitu:

\section{a. BAAk}

Memberikan data transkrip dari mahasiswa yang telah lulus tugas akhir.

b. Mahasiswa

Memberikan data umum yang berupa persyaratanpersyaratan kelulusan lain, seperti bukti-bukti mengikuti seminar nasional sebanyak tiga kali/ mengikuti studi ekskursi, memiliki nilai TOEFL minimal 450, dan lain-lain.

c. Program Studi

Program Studi akan berpengaruh pada perubahan data kurikulum yang ada dan memberikan daftar mahasiswa yang telah lulus tugas akhir. Selain itu, prodi akan mendapatkan hasil dari proses yang berlangsung, yaitu berupa laporan kelulusan dari mahasiswa yang telah lulus tugas akhir.

Entity Relationship Diagram (ERD) sistem yang dibangun dapat dilihat pada Gambar 3.

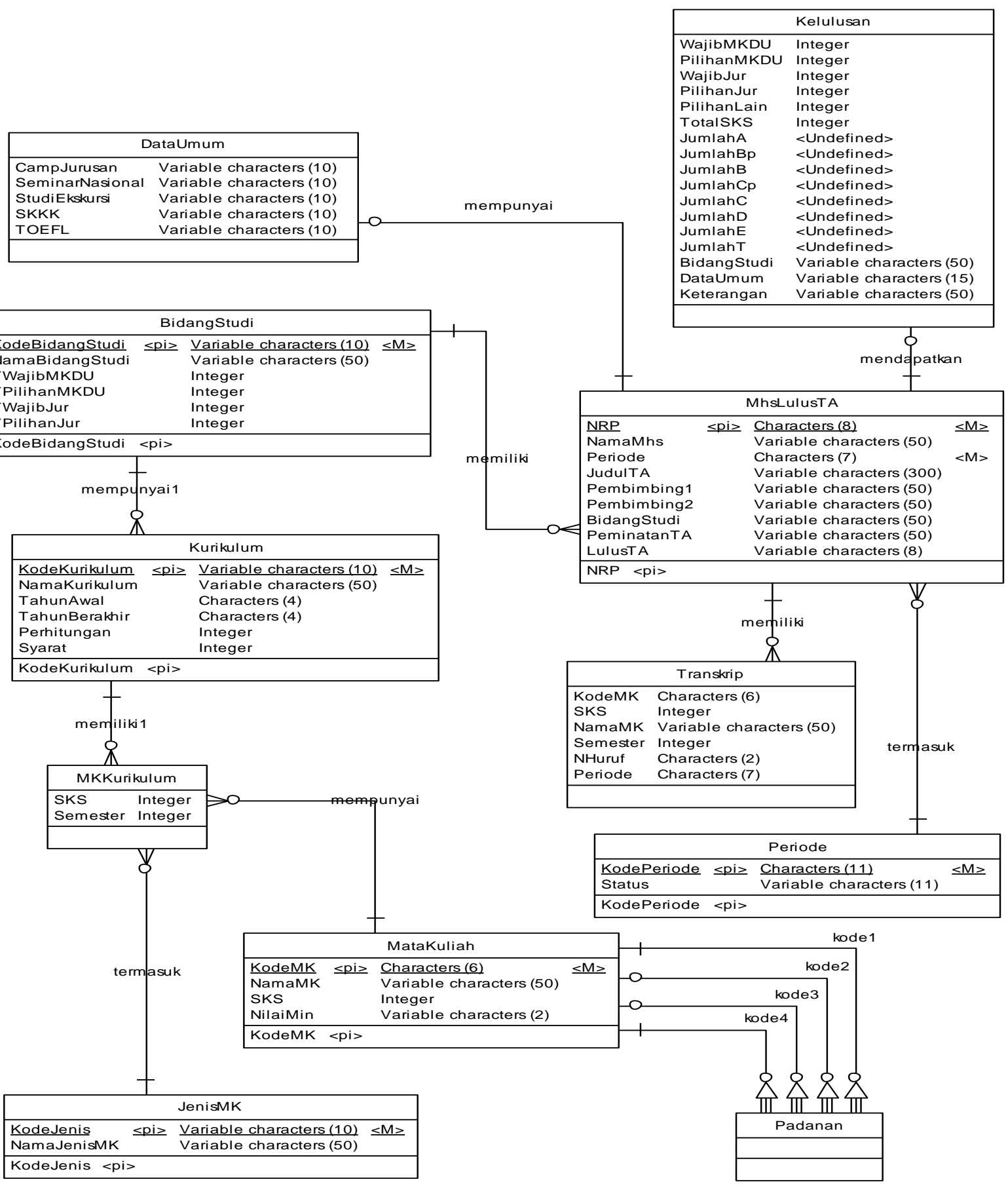

Gambar 3. Entity Relationship Diagram 


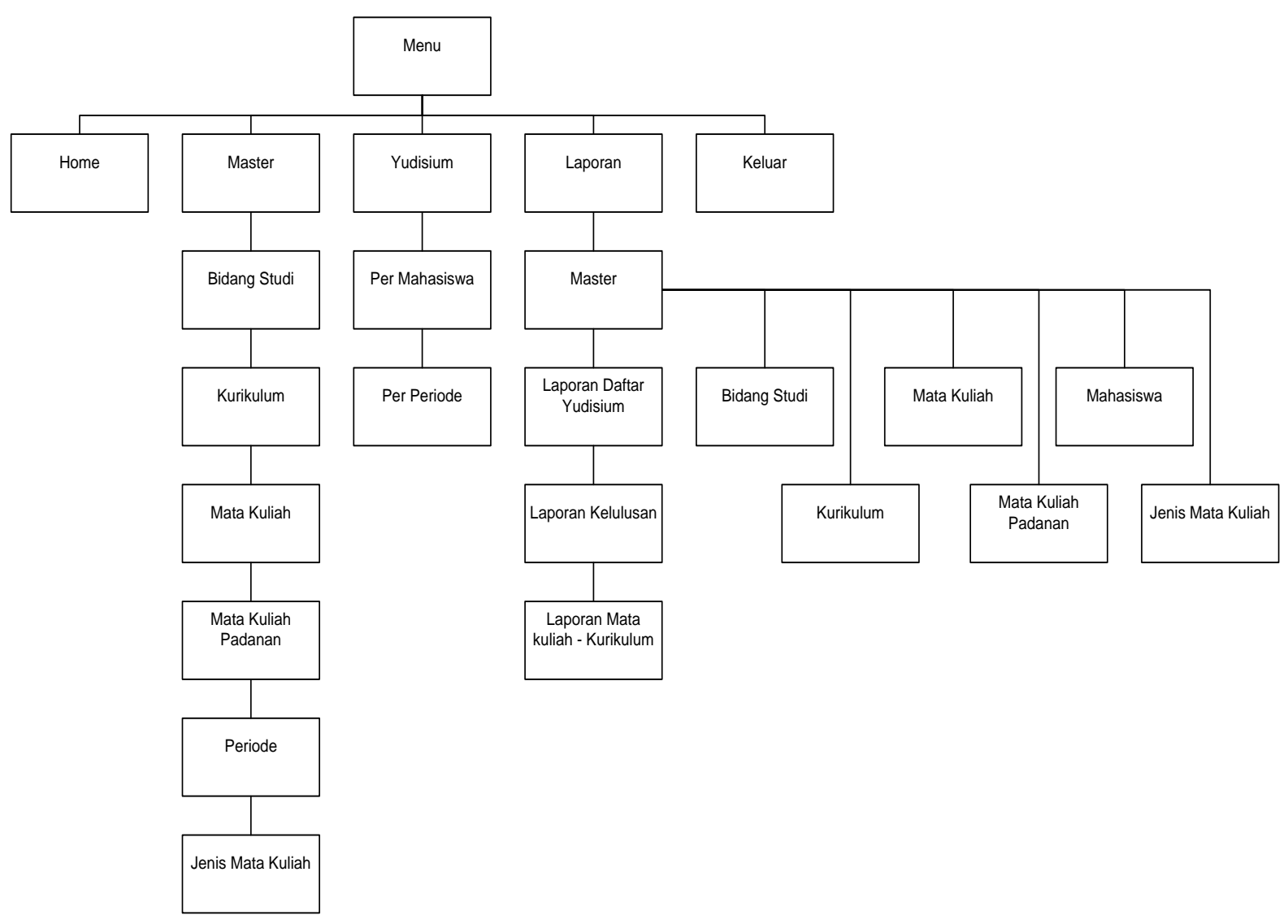

Gambar 4. Desain Menu

Gambar 4. merupakan desain menu yang dibuat untuk memberikan gambaran pada menu-menu atau fitur-fitur yang dapat dipilih dalam aplikasi web ini.

\section{PENGUJIAN SISTEM}

\section{Pengujian Aplikasi}

Pada pengujian ini didasarkan pada studi kasus dimana digunakan beberapa contoh transkrip. Hasil pengujian system akan dibandingkan dengan hasil perhitungan manual.

\section{Kasus 1: Kurikulum 2008 dan Sebelumnya dengan} Peminatan Umum

Dalam kasus ini, dari NRP mahasiswa diketahui bahwa mahasiswa tersebut angkatan 2006, sehingga kurikulum yang digunakan adalah kurikulum 2008.

Sebelum mencoba melakukan perhitungan jumlah SKS, terlebih dahulu dilakukan perhitungan secara manual. Hasil pengecekan secara manual dari transkrip 26406020 adalah sebagai berikut:

- Wajib Prodi Teknik Informatika $=100$ SKS

- Pilihan TPL =6 (18 SKS)

- Pilihan SI=4 (12 SKS)
- Wajib MKDU = 10 SKS

- Pilihan MKDU = 4 SKS

- Total SKS = 144 SKS

- Bidang Studi:

$\mathrm{TPL}=(18 / 30 * 100)=60 \%$

$\mathrm{SI}=(12 / 30 * 100)=40 \%$

Hasil prosentase untuk bidang studi TPL dan SI tidak ada yang mencapai syarat $70 \%$, maka dengan demikian bidang studi mahasiswa tersebut adalah Umum.

- Kesimpulan: Lulus.

Gambar 5. merupakan hasil perhitungan dari aplikasi pemeriksaan persyaratan yudisium. Dikarenakan bidang studi umum tidak memiliki kurikulum sendiri maka hasil pengecekan tetap memunculkan kurikulum " $k 001$ " yang merupakan kurikulum acuan dari pengecekan transkrip.

Gambar 6. menunjukkan hasil dari pengisian data umum yang merupakan syarat lain yang juga dicek dalam pemeriksaan persyaratan yudisium. Mahasiswa ini telah melengkapi data umum, maka hasil yang ditampilkan adalah "Data Umum: Lengkap".

Pada Gambar 7. diketahui tugas akhir yang diambil oleh mahasiswa tersebut adalah tugas akhir 
untuk bidang studi Sistem Informasi. Maka hasil akhir dari pengecekan tersebut mahasiswa tersebut lulus dari pemeriksaan persyaratan yudisium dengan bidang studi umum.

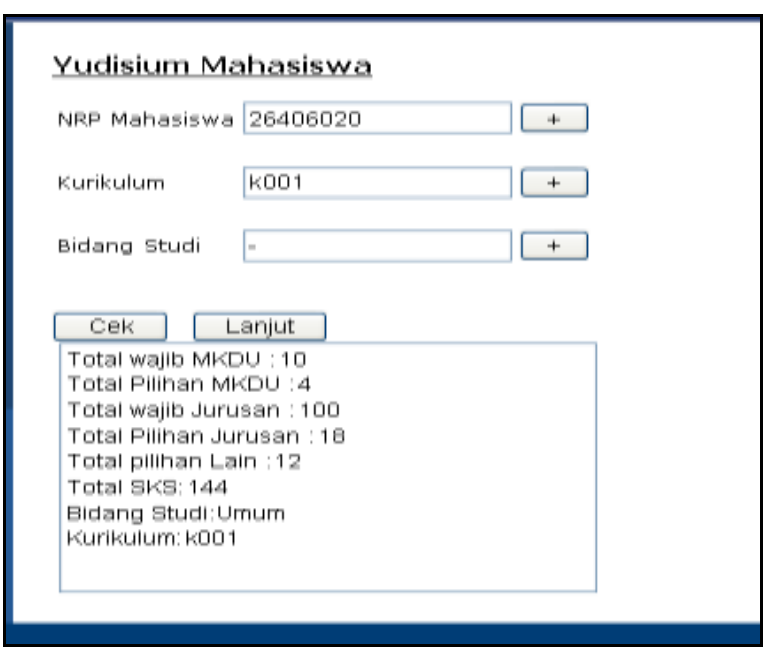

Gambar 5. Pengecekan SKS dan Bidang Studi Transkrip 26406020

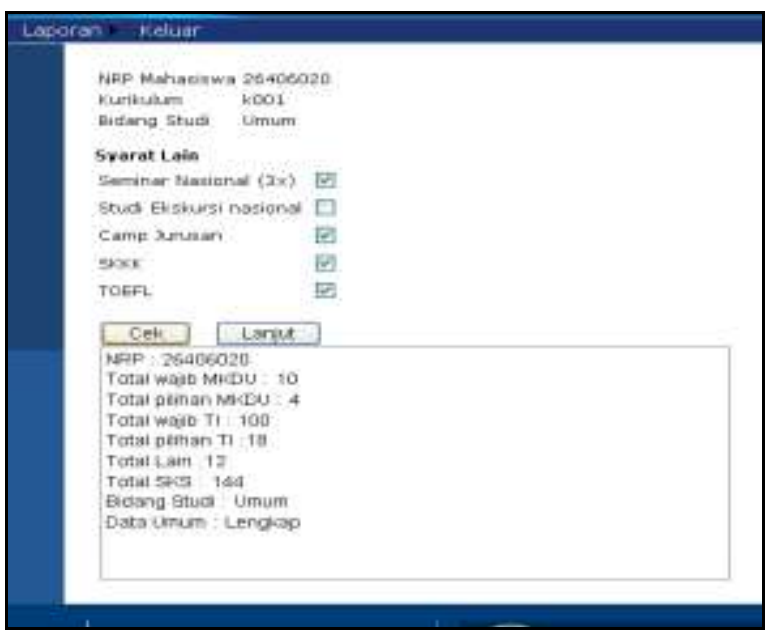

Gambar 6. Pengecekan Data Umum 26406020

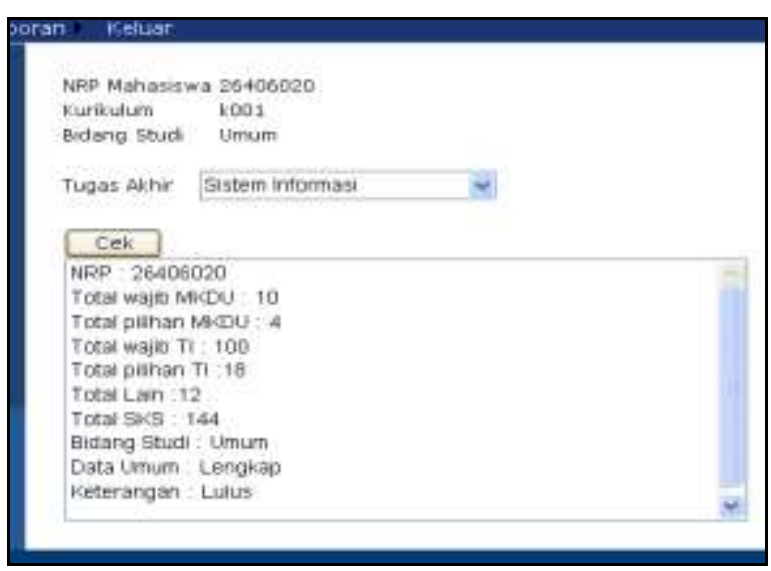

Gambar 7. Pengecekan Tugas Akhir 26406020

\section{Kasus 2: Kurikulum 2008 dan Sebelumnya dengan Peminatan Sistem Informasi}

Dalam kasus ini diketahui, mahasiswa tersebut merupakan mahasiswa angkatan 2006. Kurikulum yang akan digunakan menggunakan cara perhitungan 1.

Sebelum mencoba melakukan perhitungan SKS, transkrip terlebih dahulu dilakukan perhitungan secara manual. Hasil pengecekan secara manual dari transkrip 26406007 adalah sebagai berikut:

- Wajib Prodi Teknik Informatika = 100 SKS

- Pilihan TPL $=1$ (3 SKS)

- Pilihan SI = 9 (27 SKS)

- Wajib MKDU = 10 SKS

- Pilihan MKDU = 4 SKS

- Total SKS = 144 SKS

- Bidang Studi:

$\mathrm{TPL}=(3 / 30 * 100)=10 \%$

$\mathrm{SI}=(27 / 30 * 100)=90 \%$

Hasil prosentase untuk bidang studi SI mencapai syarat $70 \%$, maka dengan demikian bidang studi mahasiswa tersebut adalah Sistem Informasi (SI).

- Kesimpulan: lulus

Gambar 8. merupakan hasil perhitungan dari aplikasi pemeriksaan persyaratan yudisium. Dalam gambar terlihat bahwa hasil pemeriksaan menghasilkan kurikulum "k002" yang merupakan kurikulum dari bidang studi Sistem Informasi (SI).

Gambar 9. menunjukkan hasil dari pengisian data umum yang merupakan syarat lain yang juga dicek dalam pemeriksaan persyaratan yudisium. Mahasiswa ini telah melengkapi data umum, maka hasil yang ditampilkan adalah "Data Umum : Lengkap".

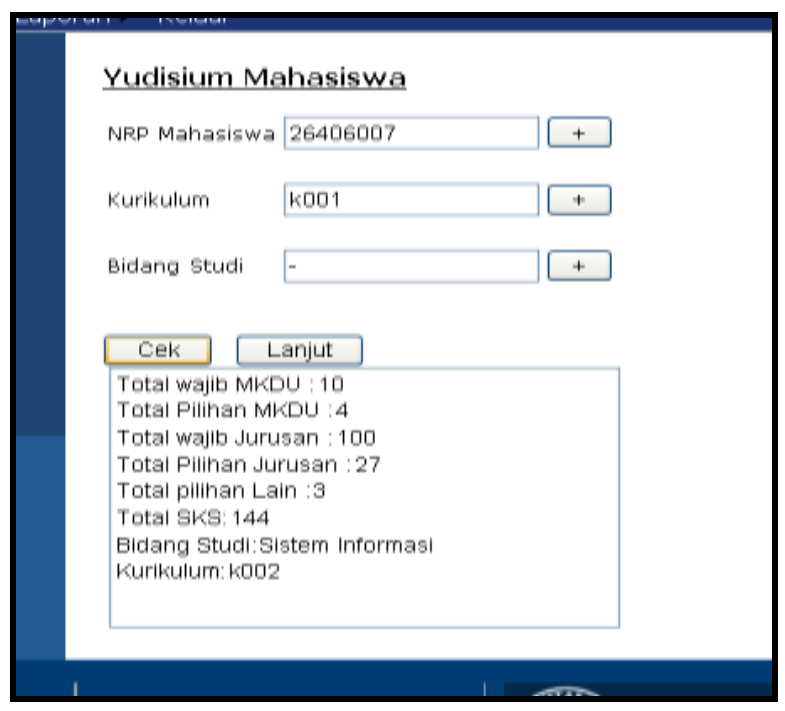

Gambar 8. Pengecekan SKS dan Bidang Studi Transkrip 26406007 


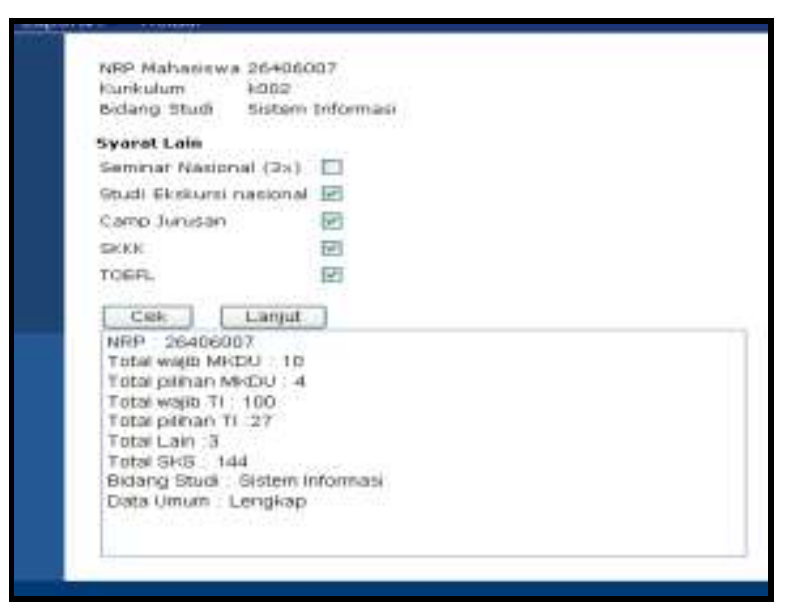

Gambar 10. Pengecekan Data Umum 26406007

Pada Gambar 10. diketahui tugas akhir yang diambil oleh mahasiswa tersebut adalah tugas akhir untuk bidang studi Sistem Informasi. Karena bidang studi dan tugas akhir yang diambil sama, maka hasil akhir dari pengecekan bidang studi mahasiswa tersebut adalah Sistem Informasi. Mahasiswa tersebut dinyatakan lulus dari pemeriksaan persyaratan yudisium karena telah memenuhi semua aspek yang diperiksa.

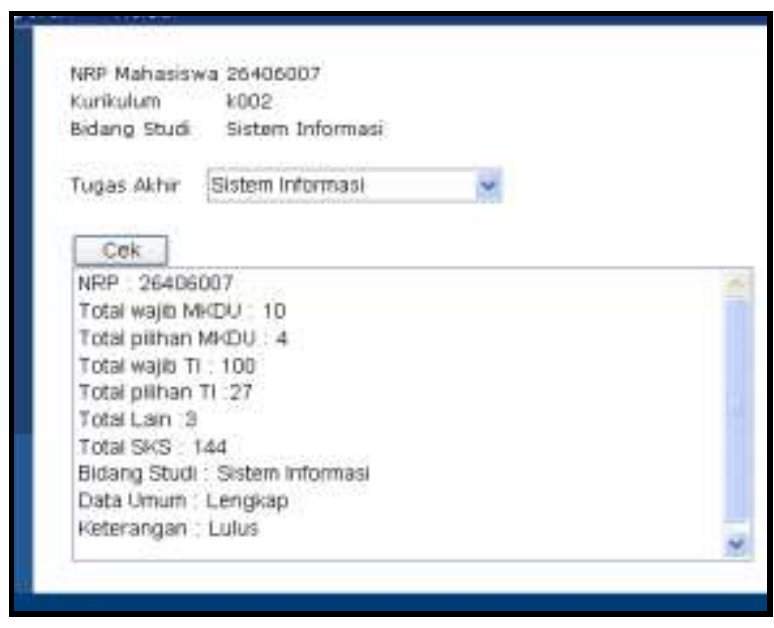

Gambar 10. Pengecekan Tugas Akhir 26406007

\section{Kasus 3: Tidak Lulus}

Penyebab ketidaklulusan mahasiswa dalam pemeriksaan persyaratan dapat disebabkan oleh kurangnya jumlah SKS dan data umum yang tidak lengkap. Dalam kasus ini akan ditunjukkan contoh pemeriksaan yang mendapatkan hasil tidak lulus.

Hasil pengecekan secara manual dari transkrip 26409000 adalah sebagai berikut:

- Wajib Prodi Teknik Informatika = 94 SKS

- Pilihan Informatika = 8 (24 SKS)

- Pilihan lain = 3 (9 SKS)
- Wajib MKDU = 10 SKS

- Pilihan MKDU = 4 SKS

- Total SKS = 141 SKS

- Bidang Studi:

Informatika $=(24 / 36 * 100)=66,66 \%$

Hasil prosentase untuk bidang studi Informatika mencapai syarat $60 \%$, maka dengan demikian bidang studi mahasiswa tersebut adalah Informatika.

- Kesimpulan: Tidak lulus. SKS pilihan kurang 3.

Gambar 11. merupakan hasil perhitungan dari aplikasi pemeriksaan persyaratan yudisium. Terlihat bahwa total SKS kurang dari 144 SKS, yang disebabkan jumlah total SKS pilihan prodi kurang dari 36 SKS (total SKS pilihan prodi = total pilihan prodi + total pilihan lain).

Gambar 12. menunjukkan hasil dari pengisian data umum yang merupakan syarat lain yang juga dicek dalam pemeriksaan persyaratan yudisium. Mahasiswa ini telah melengkapi data umum, maka hasil yang ditampilkan adalah "Data Umum: Lengkap".

Pada Gambar 13. diketahui tugas akhir yang diambil oleh mahasiswa tersebut adalah tugas akhir untuk bidang studi Informatika. Karena bidang studi dan tugas akhir yang diambil sama, maka hasil akhir dari pengecekan bidang studi mahasiswa tersebut adalah Informatika. Mahasiswa tersebut dinyatakan tidak lulus dari pemeriksaan persyaratan yudisium jumlah SKS pilihan kurang.

Pada Gambar 14. menunjukkan hasil pengecekan data umum yang tidak lengkap. Sedangkan Gambar 15. menunjukkan hasil pemeriksaan keseluruhan yang menyatakan mahasiswa tersebut tidak lulus. Hal tersebut dikarenakan oleh data umum yang tidak lengkap.

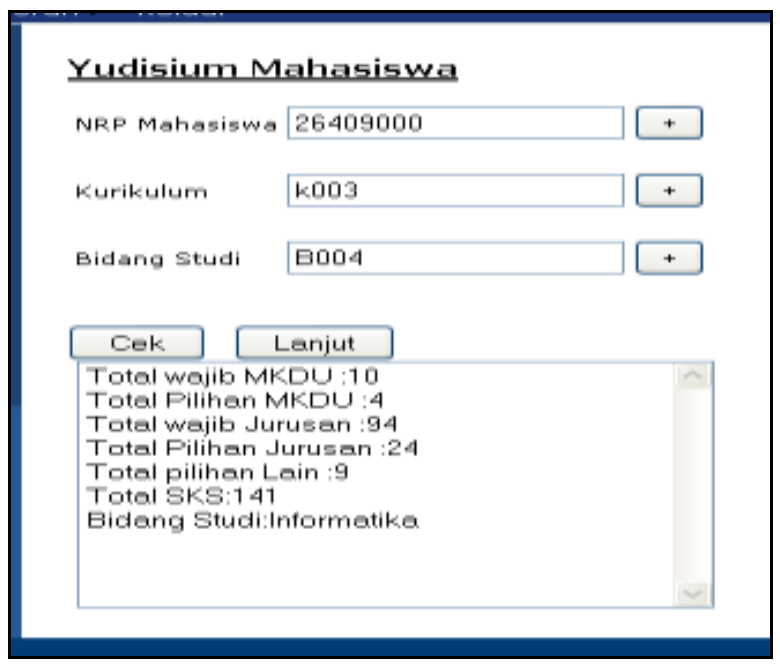

Gambar 11. Pengecekan SKS dan Bidang Studi Transkrip 26409000 


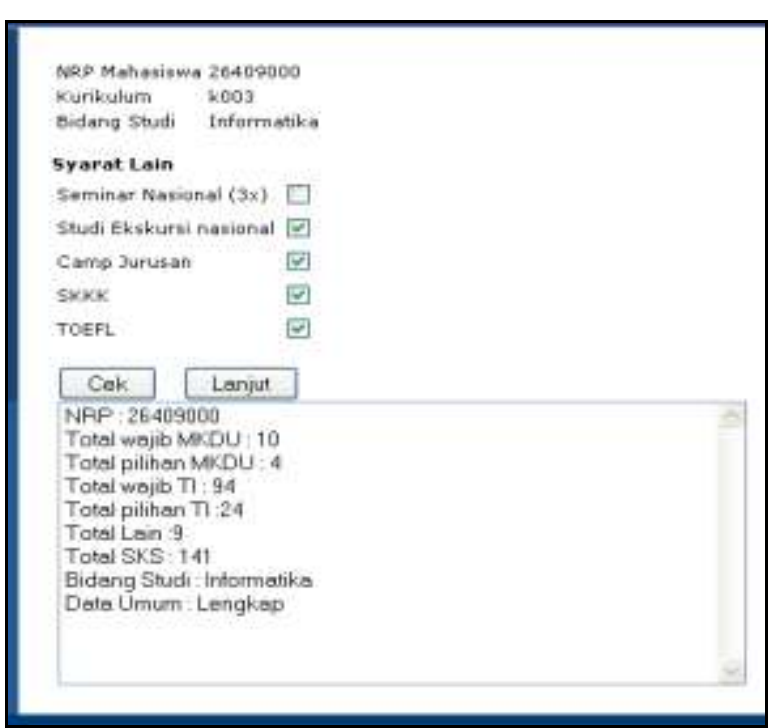

Gambar 12. Pengecekan Data Umum 26409000

\begin{tabular}{l} 
NRP Mahasiswa 26409000 \\
Kurikulum k003 \\
Bidang Studi Informatika \\
Tugas Akhir Informatika \\
Cek \\
\hline NRP: 26409000 \\
Total wajib MKDU: 10 \\
Total pilihan MKDU: 4 \\
Total wajib T1: 94 \\
Total pilihan TI : 24 \\
Total Lain: 9 \\
Total SKS: 141 \\
Bidang Studi : Informatika \\
Deta Umum: Lengkap \\
Keterangan : Tidak Lulus \\
\hline
\end{tabular}

Gambar 13. Pengecekan Tugas Akhir 26409000

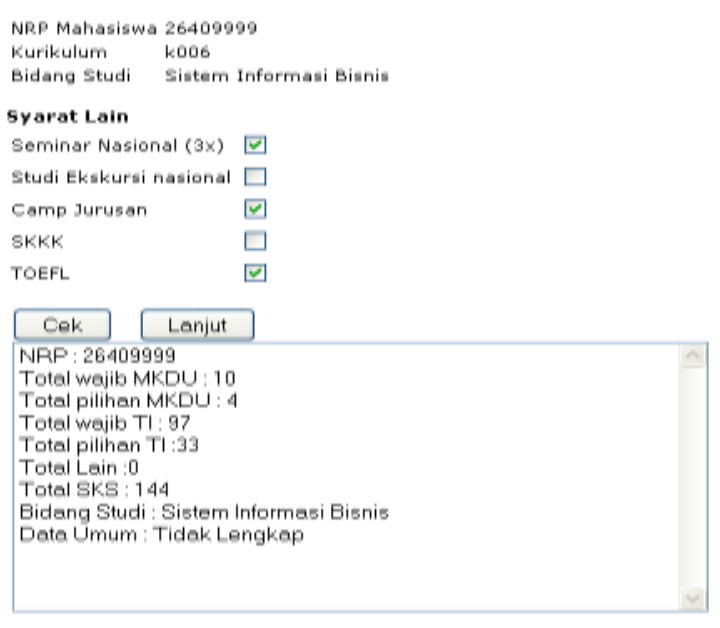

Gambar 14. Pengecekan Data Umum 26409999

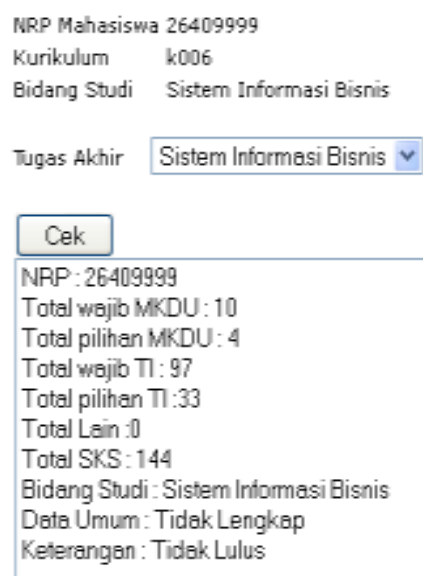

Gambar 15. Pengecekan Tugas Akhir 26409999

\section{Kasus 4: Yudisium per Periode}

Pemeriksaan persyaratan yudisium tidak harus dilakukan dengan memeriksa satu per satu transkrip. Pemeriksaan dapat dilakukan langsung dengan membaca transkrip-transkrip yang ada berdasarkan periode mahasiswa-mahasiswa tersebut mengajukan tugas akhir. Periode yang akan diperiksa dapat diatur pada halaman Home.

Pada Gambar 16. menunjukkan hasil pengecekan SKS dan bidang studi. Gambar 17. merupakan pengisian data umum yang dilakukan dengan menggunakan menu yang terdapat pada samping tabel untuk mengisi. Gambar 18. menunjukkan hasil dari pengecekan tugas akhir dan keseluruhan.

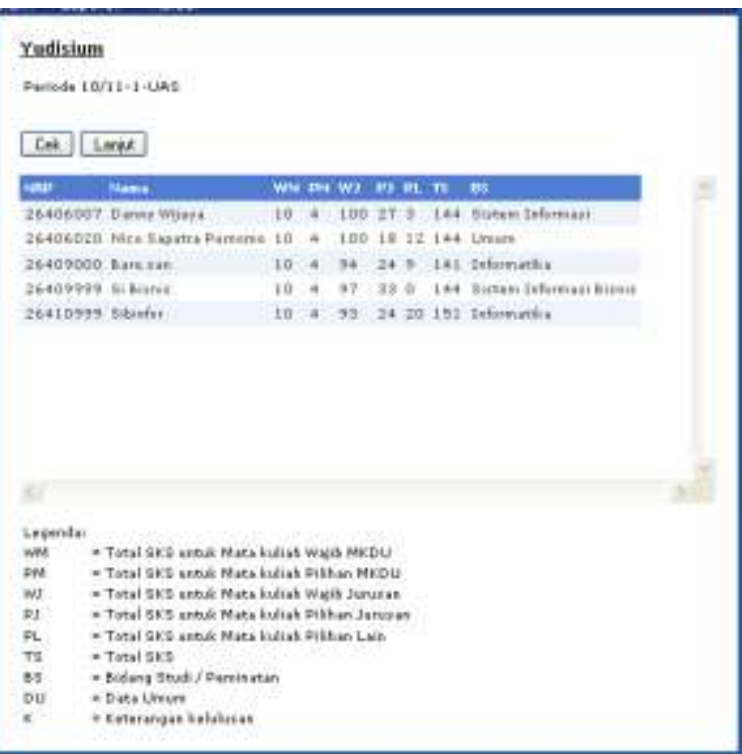

Gambar 16. Pengecekan SKS dan Bidang Studi Periode 10/11-1-UAS 


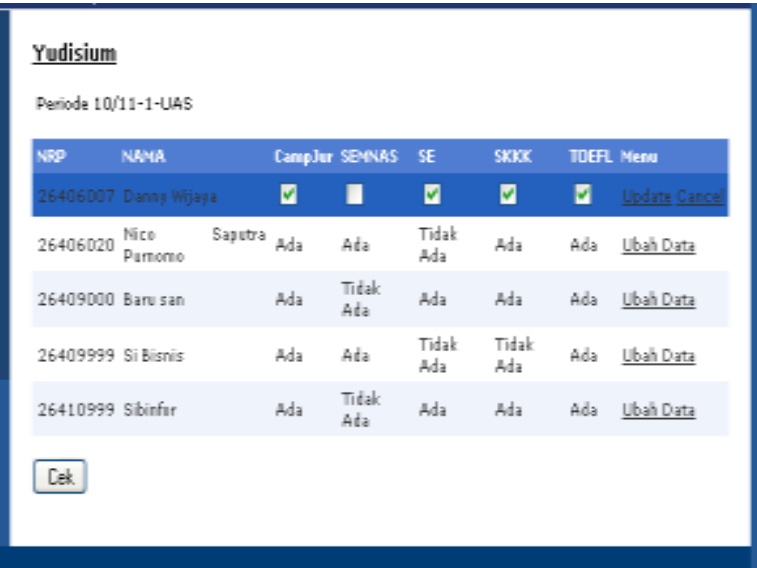

Gambar 17. Pengecekan Data Umum Periode 10/11-1UAS

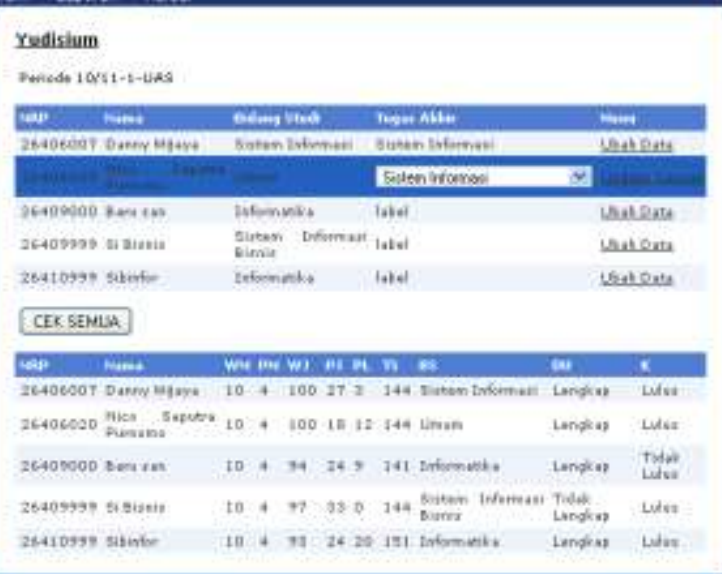

Gambar 18. Pengecekan Tugas Akhir Periode 10/11-1UAS

\section{Pengujian kuisioner}

Kuisioner pengujian aplikasi dibagikan kepada empat orang dosen di Prodi Teknik Informatika yang berwenang dalam proses yudisium di Prodi Teknik Informatika.

Berdasarkan dari penilaian kuisioner dengan nilai 4 dan 5 didapatkan:

- 75\% responden mengatakan bahwa aplikasi ini mudah digunakan.

- $100 \%$ responden mengatakan bahwa tampilan aplikasi sudah baik.
- 75\% responden mengatakan bahwa fitur-fitur sudah memadai.

- $100 \%$ responden mengatakan bahwa aplikasi ini sudah sesuai dengan yang dibutuhkan.

- $100 \%$ responden mengatakan bahwa aplikasi ini secara keseluruhan sudah baik.

\section{KESIMPULAN}

Berdasarkan hasil pengujian sistem, dapat disimpulkan beberapa hal sebagai berikut:

- Membantu mempersingkat waktu yang digunakan dalam proses pemeriksaan.

- Meringankan beberapa inputan manual seperti data transkrip dan data mahasiswa.

- Dapat mengatasi kasus-kasus untuk kurikulum lama dan kurikulum baru. Dan dapat mengatasi perpindahan bidang studi.

- Berdasarkan hasil kuisioner, aplikasi ini dinilai dapat memenuhi kebutuhan Prodi Teknik Informatika dalam pemeriksaan persyaratan yudisium. Hal ini terlihat dari hasil pengisian kuisioner pada pertanyaan nomor 4 mengenai kesesuaian aplikasi dengan kebutuhan. Untuk pertanyaan ini, $100 \%$ responden menjawab sudah baik.

Untuk kedepannya, diharapkan data yang diolah dapat langsung diambil secara online dari BAAk, dengan membuat program untuk BAAk yang dapat mempermudah pengambilan data transkrip.

\section{DAFTAR PUSTAKA}

1. Universitas Kristen Petra. 2010. Buku Pedoman Jurusan Teknik Informatika 2007-2010.

2. Deitel, H.M. \& Deitel, P.J. (2006). Visual Basic 2005 How to Program $3^{\text {rd }}$ ed. New Jersey: Pearson Educational, Inc.

3. Welling, L. \& Thomson, L. (2008). PHP and MySQL Web Development $4^{\text {th }}$ ed. AddisonWesley.

4. Pohan, H.I., \& Bahri, K.S. (1997). Pengantar perancangan sistem. Jakarta: Erlangga.

5. Hoffer, J.A., Prescott, M.B. \& Topi, H. (2009). Modern database management $9^{\text {th }}$ ed. Pearson Educational, Inc. 